\title{
Determinants of Dividends Payout and Policy Used In Emerging Economies: Evidence from Turkey
}

\author{
Zakayo S. Kisava \\ Graduate School of Social Science- Dokuz Eylul University, Turkey \\ E-Mail: samsonzaki@yahoo.com
}

Fredynandy M. John

The Institute of Finance Management, Tanzania

E-Mail: fredynandyjohn@gmail.com

Received: September 28, 2017 Accepted: October 15, 2017

doi:10.5296/ber.v7i2.11921 URL: https://doi.org/10.5296/ber.v7i2.11921

\begin{abstract}
The study is focused on the determinants of dividends payout and policy in the emerging economies, as the sector is too significant and gets more attention from large number of researchers in financial area as well as accounting because of its contribution in the economy. The scope of the study went throughout 2005 to 2016 years, the selected time was theoretically analyzed and studied to understand determinant of dividends payout and policy used in emerging economies in comparison to countries with emerged economy. The study used Turkey to represent emerging economies since it is among the fast growing economy despite political and economic issues it goes through.

The study theoretically confirmed that size level, profitability size, retained earnings, net income, and debt level are the determinants of dividends payout and policy and are some of the significant factors. Additionally, through these factors we identified that emerging economies use unstable policies in comparison to developed economies. This study is too significant to investors since it will assist them to understand features of financial markets and companies listed or trading in those financial markets. Furthermore, the paper will assist financial managers to comprehend the significance of factors such as net income, cash balance, retained earnings and companies' profitability in the process of dividend payments whilst maintaining stable financial position of the business.
\end{abstract}

Keywords: Dividends Payout, Dividend policies, Emerging economies, Istanbul Stock 
Exchange (ISE), Profitability

\section{Introduction}

A dividend policy is predominantly concerned with the financial markets decision on dividend payout as well as retention or reinvestment.

Ronald C. Lease et al. (2000) stated that practice embraced by financial market managers' implements dividend payout decisions. It explains the amount of fund to be disbursed to every shareholder as well as the amount to be withhold by the financial market for reinvestment. The major objective of any firm's dividend policy is to keep leading and consistent in maximizing investors wealth as the earned return from their investment. Many studies have been done from developed economies like Western Europe and North America without paying much attention to emerging economies.

A dividend decision is the highest significant financial decision of a firm since firms make effort to term the level of internal financial resources and how to maximize the shareholder's wealth through dividend. In hypothetical context, dividends have been a major research and controversial area in finance since dividend payout and policy act as the engine to financial shareholders' life of investment Miller and Modigliani (1961).

Numerous of financial issues and ideas including those of asset pricing and capital budgeting, capital structure theories, and mergers and acquisitions are nearly related to the discussion and topics on how and why all firms pay out dividends to their shareholders. In any firm or financial market, the determinants are used as guidance to help analysts to understand the dividend puzzle to some degree, based on these determinants many scholars have determined and examined dividend factors that influence dividend payout decisions of firms.

The hypothetical models of dividends are highly based on the impacts of taxes, transaction costs, agency costs, clientele effects and information content and Sometimes shareholder's preferences. Generally, the dividend determinants depend on specific factors of the firm that influence the dividend payout ratios. Earlier studies indicates that industry, size, capital structure, profitability, ownership structure, maturity of the firm and ownership structure as well as firm's level factors are all contributing to dividend payouts.

\subsection{Background and Significance of the Study}

The main focus of this study is to determine the determinants of dividend policy on emerging economies as evidenced from Turkey's stock market: The study uses companies listed in Istanbul Stock Exchange (market) over the period of 11 years with interest in determinants of dividend payout during global financial crisis of 2007 and afterwards. Previous studies that were conducted based only on factors, which influence the distribution of dividend payout ratios, but not on the dividend policies, which are used as tool towards dividend decision making for payout. The study is of paramount importance to dividend policy managers as well as government, and regulators to understand different determinants of dividend policies in Turkey as part of the emerging markets in the world. Moreover, it will add much contribution to financial literatures particularly those of emerging markets since majority of 
literatures are based on the developed economies such as the USA and the UK.

\section{Literature Review}

The original study in examining the determinants of dividend policy and payout are done by Lintner (1956), where different approaches were used including empirical and survey research methodology to make analysis. In his literatures on determinants of dividend policy he detected several variables totaling to 15 some are; willingness to use external financing, firm size, use of stock dividends, plant and equipment expenditures, and earning stability and ownership by control groups. The empirical work of Lintner (1956) came up with findings that define a goal of a target dividend payout ratio and dividend policy. This is through making some adjustments that depends on the targeted dividend payout ratio that guarantees the sustainability of the firm's capital investment to achieve its expected growth in both short and long run but with much focus on long run targets. On the other hand Lintner (1956) came up with another finding that proves on firm's managers consider that investors always prefer corporations, which chart on with stable dividend policies.

Kuzucu (2015) took a research to make a perception test and knowledge of the financial controllers on firm's dividend policy of some of the listed, and those that are non-financial firms. His findings proposed that the most influential factor to payout decision is the earnings. Also specified the most important determinants of dividend policy in the Turkish market; stability and level of forecasted earnings, sustainable change in earnings, financial leverage and equal distribution of proportion of earnings to investors. Additionally, he went far by taking a step to examine the firm's share repurchase decision in Turkey under the umbrella of financial managers' opinions. Then the conclusion defined that; share repurchase decision is the most determinant that is undervaluation on the stock price.

Adaoglu (2000) examined BIST companies' dividend policy behaviors on whether they align with the stable dividend policy as compared to developed markets' companies, results concluded that BIST companies' follows unstable dividend policy contrasting to developed markets. Adaoglu applied Lintner's dividend model to examine the permanence and regulation effect, again results proved that companies listed under BIST for the period of 1985 to 1997 used unstable dividend policy, this instability highly accelerated after the endorsement of regulation change in 1995. The final conclusion that found that major determinants of dividend are earnings and the level of instability that exist in the BIST companies' led to instability of dividends in the market.

Adaoglu (2008) analyzed BIST companies' dividend behavior from 1986 to 2007, analysis based on concentration of dividends and its disappearance in the market (Turkey). Findings depicted that as dividend level increases, the real number of payers' decreases. These results were aligned with that from the United State of America (USA) done by DeAngelo et al (2004) where, he discovered that as the payout ratio increases also on the other hand industrial companies' size increases.

Yilmaz (2003) analyzed BIST firms' dividend policy from 1986 to 2001 by taking into consideration the industrial differentiation. He confirmed that during 1995 firms under BIST 
were not paying out dividend because the mandatory dividend payout was abandoned. Net cash dividend was employed as formation that means the cash dividend to rights offerings. Then confirmed that after the abolishment of the mandatory dividend payout in 1995 average payout ratio on financial sectors faced a suddenly slow down as the result led to decrease in dividend payers in comparison with other industries under BIST.

Altiok, Yilmaz and Akben (2010) used dividend information change announcement to test market reaction over BIST listed companies' from 2005 to 2008, event study methodology were used. Their conclusion confirmed that market reacts positively or negatively over the dividend information announcement, but no reaction in the time when dividends remain constant.

Yurtoglu (2000) assessed all BIST companies' ownership structure in Turkish, findings depicted that companies with concentrated ownership lead to a negative relationship of return on assets, dividend payouts and price to book ratios. Then he concluded that concentration companies' ownership leads to a negative performance to the listed companies in the market.

Kirkulak and Kurt (2010) conducted a study on dividend policy for the companies based on BIST for a period from 1991 to 2006 and their findings suggested a decrease in number of the payers and real dividend amount. Also reported a decrease of dividends and earnings concentration for the same period. Furthermore, they investigated determinants of dividend decision and found that high growth potential and earning are the main determinants among: earnings, high growth potential and dividend there is a positive correlation.

Aivazian, Booth, and Cleary (2003) conducted a study to analyze the factors that determine dividend policies for eight (8) years on emerging markets including Turkey by making comparison of dividend behaviors of companies under emerging market against the one in USA. The results suggested that; leverage, price to book ratio, profitability and size are the major determinants of dividend policies in emerging markets. Hence, they concluded that the companies in the emerging economies follow unstable dividend policies.

Referring to other literatures, show that firm's risk level is considered as one of determinants of dividend and there is a negative relationship between dividend policy and firm's risk level. Rozeff (1982) came out with findings that showed there is an existence of negative relationship between firm's risk level and dividends. Again, Grullon et al. (2002) studied the relation between the change in systematic risk and change in dividends; their findings reported that firm experiences a significant increase-decrease in their systematic risk then dividend decrease-increase. The justification towards their study showed that as the firm matures also the opportunities to investors gets lower. In other way around there are numerous literatures in finance on dividend policies for well-established markets in contrary to emerging market stocks.

Michel (1979) offered out evidence on dividend policy that firm's industry has a big influence over the policies. He proved that dividend payouts have a positive relation with industrial category. In his study, Rozeff (1982) found that industrial firm was silent about dividend payout ration purposefully except the utilities firms based on his analysis and was 
highly contributed by their regulatory status.

The most surveyed and research determinants are profitability and size of the firm in relation to dividends. Jensen and Meckling (1976), Donald, Jensen and Zorn (1992) proved that firm size and profitable was rated high in terms of dividend payouts. Smith and Watts (1992) by using industrial level data found that dividend yield is directly related to firm size and concluded that profitability and firm size are the most determinants of dividend.

Von Eije and Megginson (2007), in 15 nations based in the European Union detected a decrease in number of firms paying dividends; the decrease was noticed from $92 \%$ up to $62 \%$ for the year 1989 to 2003 . However, on the other side there were a significance increase in real dividends and payments together with the sharp increase in earnings and dividend concentration. The same behavior was again detected in the firms of the United State of America. Ferris et al. (2006) conducted a research as a repetition on the same study and found similar results in the United Kingdom firms'. The results showed as significant decrease in percentage of dividend payers from $75.9 \%$ to $54.5 \%$ for the years 1988 to 2002 . Another study was extended to Japan and went far by doing international study that involved 30 countries. The findings showed that there were a high dividend and earnings concentration and a sizable deviation in the tendency to pay dividends. Denis and Osobov (2008) analyzed the study, which involved both developed and developing, they recognized that the total dividends were not decreasing and were focused among the largest and best profitable firms, and those with high retained earnings formulating up a substantial fraction of total equity.

Reddy and Rath (2005) examined the problem for the decline of dividend for emerging market by taking Indian market as the evidence; their findings were alike to dividend features of Indian industrials. They managed to find the decrease in percentage of dividend payers for the year between 1991 and 2001, and fall in propensity to pay dividends, and part of their findings showed that dividend payers firm is more profitable compared to non-paying industrial.

Aivazian et al. (2003a and 2003b) used a variety of data set from emerging markets and Turkey was included, the results displayed that dividends are well explained by profitability, debt, and the market to book ratio, this concluded the view that emerging markets follow unstable dividend policies decreasing the function of dividend as policy signing device.

A number of researchers in finance and accounting subjects have expressed their interest by studying the most important topic to determine dividend policy and dividend payout, Lintner (1956) came up with a proposal as part of his findings that most of the firms presumed to match with the desired dividends based on the expected earnings. Dividend policy is determined by the change in the level of earnings. Babiak and Fama (1968), Gitman and Pruitt (1991) and Baker and Powell (1999) aligned with Lintner's results. Additionally, Skinner and Soltes (2011) analyzed the correlation between earnings quality and dividends; their findings proposed that there is a stronger relationship between dividends and earnings as dividends helps to clearly provide information concerning the sustainability of the company's earnings. This simplified by dividend payer companies in comparison to non-payers, those companies that pay dividends are believed to have a stronger relationship between dividends 
and the future expectation earnings.

\section{Research Methodology}

\subsection{Population, Sample and Scope}

This paper is focused on analyzing the determinants of dividend payout and policy in emerging markets. Since Turkey is considered amongst fast growing emerging economies, Istanbul Stock Exchange (BIST) is selected for the study purpose in which listed companies were used to analyze the subject towards dividend polices as well as dividend payouts. A total number of 546 companies are listed as 2015 statistics but from this population of firm the study employed part of it as sample for the period of 11 years from 2005 to 2016. The duration from 2005 to 2016 included global financial issue such that of 2007 to 2009 that helps to understand the dynamist of the dividend policies as well as its determinants. This period suit to understand which policy does the emerging markets follow.

\subsection{Data Sources}

This research uses secondary data of the listed companies trading in the Istanbul Stock Exchange however, the sample do not include all listed companies due to reasons such as accessibility and availability of data, different regulation boards, and to avoid unbalanced data from missing information. The selected listed companies are from various economic sectors such as insurance companies, banks, investment companies, investment trust institutions and factory companies. Electricity, gas and water form a group known as utility firms and their regulations and governance are different in terms of dividend policies.

\section{Relationship between Dividend Policy and Size of the Firm}

Mormah, Norhayati, Wee and Rashidah made their study based on market capitalization for Malaysian firms, about 200 companies for the period of over 3 years that ended in 2005, concluded that big companies decide to pay higher dividends. Baker et al. (2007) all companies that pay good and high dividends to its shareholders in Canada are highly categorized as larger and more profitable, with developed cash flow, well-organized structure and growth forecasts.

Naceur et al. (2006) developed a research to study dividend policy by using Tunisian Stock Exchange which included 48 listed companies for the years from 1996 to 2002. The findings portrayed those profitable companies, with high earning sustenance large free cash movement and pay greater dividends.

\subsection{Relationship between Dividend Policy and Liquidity}

Ho, H. (2003) used Australia and Japan to find the relationship between dividend policy and liquidity; they confirmed that size and liquidity positively influence dividend policy. Dividend policy is significantly determined by liquidity, a company with poor liquidity position will always have shortage of cash to meet its financial needs as well as to pay out dividends.

Alli et al. (1993) the capacity of the company to pay dividend depends on the cash flow of the 
company rather than current earning that in one way to be manipulated by accountants. The reality is company capacity to pay dividends is not represented by the current earnings and if the company is not associated with cash flow will not opt for high dividends payout because will automatically be force to slow down its investment projects or go out and seek for additional fund as debt. Brook, Charlton and Hendershott reinforced the same argument in 1998 firms that were anticipating extra enlargement in their long-lasting cash flow that raised their firm's dividend. Belans et al. (2007) confirmed that in their study, firms that hold high market liquidity are expectedly to fall under high dividend payment compared to those with low market liquidity. But, Abor and Amidu (2006) in their study identified a contrasting relationship.

Bacon's and Myers (2001) in their research presented that there is a negative correlation between dividend payout and liquid ratio, thereafter in 2002, Brealey-Myers theorized that if managers of the firms are not assured of their firm's cash flow to tie-up with dividend payment they will not be in a position to announce dividends.

\subsection{The Relationship between Dividend Policy and Profitability}

Aivazian, Booth and Cleary (2003) conducted a study that portrayed a positive relationship between profitability and return on equity to dividend payout ratio. Fama and French (2001) believed that dividend decisions and policies are mainly influenced by the following factors as internal and external forces to the company's decision: Investment opportunities, profitability and Size. Fama and French studied companies in United States and came up with the conclusion that one fifth of all the companies which are publically listed pay no dividend, one of them Microsoft and Cisco. Their conclusion confirmed that companies that are associated with profitability and size always pays out dividends to its shareholders, inversely to companies that are associated with growth. The same to the study conducted by Jennifer and Kenneth (1993) said that a growth opportunity is directly correlated to the dividend yield of the company. The argument behind is that all of small firms are believed to have the best investment opportunities that cause them to avoid paying dividends to its shareholders, because as cash flow increases result to a decrease in dividend coefficient.

\section{Determinants of Dividend Policy}

All firms at the end of the year before they announce the distribution of dividends to shareholders, the management must take into concern the amount of fund they want to hold to meet their financial requirement as company to run their daily operation. Nevertheless, these decision are mainly determined by the following factors:

\subsection{Companies'Profitability}

It is important for a company to ensure it maintains profitable graph since dividends are paid out of profits, so it is unrealistic for unprofitable firm paying dividends continuously as from the past retained earnings or profit. Lintner (1956) verified that net earning is the most important to be taken care since it stands as the major motivating factor of the firm to pay dividends to it's shareholders. Additionally, in case the cost of debt and equity are to be taken into consideration, then only high profitable firms would be able to announce and pay out 


\section{Macrothink}

dividends to its shareholders inversely proportion to low profit companies. "Pecking order theory"

\subsection{Net Income}

Net income is referred as the income or fund after taking out all taxes, expenses, and interests. A firm will confidently declare to pay dividend when its net income is stable, this is because net income is directly correlated to dividends payment. Examples, firms that are highly profitable are expected to pay out high dividends.

\subsection{Cash Balance}

For the firm to announce cash dividend must have reliable cash at its level of deposit. Firms with poor working capital are always in a position of not to pay out and adopt liberal policy of cash dividend which is highly used in the world and forced themselves to payout dividends through other forms. Alli et al (1993) announced that payment to shareholders (dividends) are highly influenced by cash flows while Brealey-Myers (2002) confirmed that firm's manager will not declare any raise of dividends otherwise are optimistic at the future will have adequate cash flows.

\subsection{Company's Debt}

Company's debt is when a firm acquires fund via debt, by that time it creates a new and fixed financial liability that includes paybacks as principal amount and interest that varies in respect to percentages agreed. Failure to fulfill or comply with the agreement may result the firm into impoverishment. This situation may cause a high level of financial leverage rises the risk of low dividend payments to shareholders and paying other liabilities as daily operation activities. Additionally, must ensure a sustainable internal cash flow to meet liabilities as firm and cover all other external forces. The statement had been reinforced by Rozeff (1982) quantified that firms with high gearing are likely to have low payout rate.

\subsection{Retained Earnings}

Retained earnings are considered as earnings stored by the firm as forecasts for the future use, and are considered as the outstanding indicator of the firm's possible dividend policy. Additionally, retained earnings are used to estimate or forecast financial performance of the firm in a general understanding and perspective of accounting.

\section{Key Graph and Table}




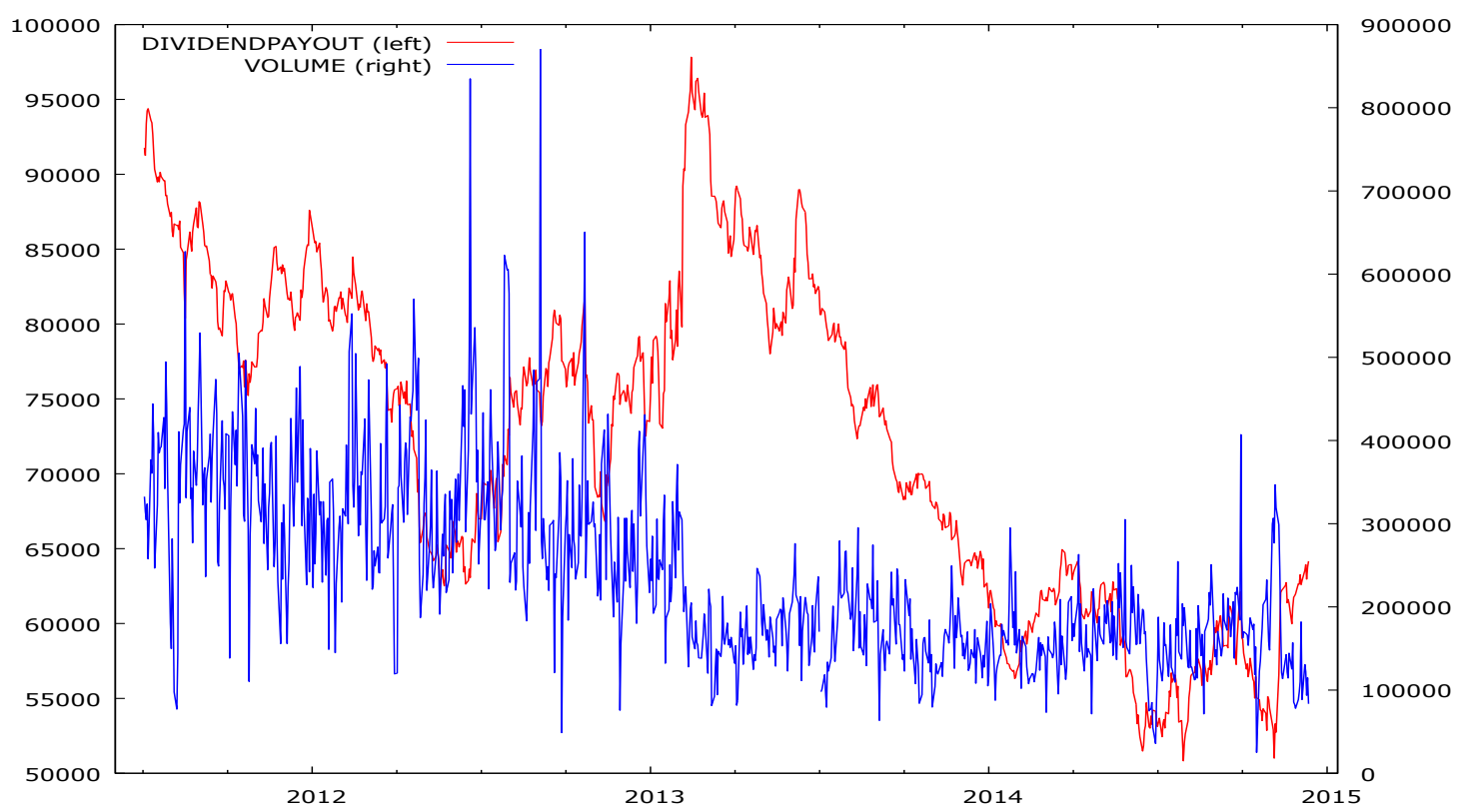

Figure 1. Dividend Payout and Trading Volume July 2011 to July 2015

Figure 1 above depicts the relationship between dividend payout and the trading volume of the stocks of the listed companies at the Istanbul Stock Exchange from 2011 to 2015. Higher payout is observed in years 2011 and 2013 while lower payout is observed in years 2012, 2014 and 2015. A tumultuous trend of the trading volume is noticeable over those years. Again, in the Table 1 below a decrease in the payout amount is noticed in the years 2014, 2015 and 2016. The relationship between dividend payout and the trading volume should be clearly understandable to all financial practitioners for them to make viable investment decisions worth their funds.

Table 1. Historical Dividend Payout by the Listed Companies of the ISE

\begin{tabular}{|l|r|r|r|l|l|}
\hline \multicolumn{7}{|c|}{ Dividend History } \\
\hline Payout Amount & Declared Date & Ex-Dividend Date & Pay Date $\boldsymbol{\nabla}$ & Payout Type & Frequency \\
\hline$\$ 1.0280$ & $19 / 06 / 17$ & $20 / 06 / 17$ & $26 / 06 / 17$ & Regular & Semi Annual \\
\hline$\$ 0.0512$ & $20 / 12 / 16$ & $21 / 12 / 16$ & $28 / 12 / 16$ & Regular & Semi Annual \\
\hline$\$ 0.8860$ & $21 / 06 / 16$ & $22 / 06 / 16$ & $28 / 06 / 16$ & Regular & Semi Annual \\
\hline$\$ 0.0108$ & $18 / 12 / 15$ & $21 / 12 / 15$ & $28 / 12 / 15$ & Regular & Semi Annual \\
\hline$\$ 1.0946$ & $24 / 06 / 15$ & $25 / 06 / 15$ & $01 / 07 / 15$ & Regular & Semi Annual \\
\hline$\$ 0.8836$ & $24 / 06 / 14$ & $25 / 06 / 14$ & $02 / 07 / 14$ & Regular & Semi Annual \\
\hline$\$ 1.1171$ & $26 / 06 / 13$ & $27 / 06 / 13$ & $05 / 07 / 13$ & Regular & Semi Annual \\
\hline$\$ 1.0131$ & $20 / 06 / 12$ & $21 / 06 / 12$ & $28 / 06 / 12$ & Regular & Semi Annual \\
\hline
\end{tabular}

Source:

http://www.dividend.com/dividend-stocks/uncategorized/other/tur-ishares-msci-turkey-invest able-market-index-fund/ 


\section{Conclusion}

Our study focused on determinants of dividend payouts and dividend policy in emerging economies for the period of 2005 to 2016, evidenced from Istanbul Stock Exchange (ISE) in Turkey. ISE is considered among the fast growing financial market despite all internal and external political and financial problem faced by Turkey. External effects are coming from Europe and America considering these are among the powerful economies in the world with strong and determined financial markets.

This study is among the few papers studied about determinants of dividend payout using theoretical reviews of the past literatures and the current position of the financial market in Turkey. Theoretical review was preferred as the result of difficulties in obtaining the required information for analytical parts. The findings from the study showed that ISE comprises both big and small size companies that operates under the umbrella of Istanbul Stock Exchange, companies are classified as big or small by considering features like size, profitability level, liquidity level, net income, retained earnings, debt, growth rate, and cash balance.

Companies with higher retained earnings are considered to have behavior of regularly paying out dividends to her shareholders or investors; this is inversely related to companies with lower retained earnings. Profitability of the companies takes a significant role in paying dividends out to investors, higher profitable companies always pays dividends compared to lower profitable companies because they focus on growth. Cash balance has a significance role as determinant of dividend since any company that declares dividends payout must have sufficient cash balance to sustained investment and normal operation of the company as daily flow to the company, also dividends are paid as part of the cash balance in the company. Profitability level of the company determine both sides of the company's status to whether of being able to declare a dividend payout or not since dividends are paid from the profit of the company.

Dividends policy in the emerging economies especially Istanbul Stock Exchange are directly explained by profitability, debt, and the market to book ratio. This supports the view that the uses of unstable dividend policies by emerging markets decrease the function of dividend policy as a signing device.

\subsection{Future Research}

Even though this theoretical study is significant to the industry and provide insights for investors to understand different determinants of dividends, we encourage future research to extend the study by employing different methods such as quantitative research after obtaining financial data. Such method will give better and clear figures for analysis.

\subsection{Recommendation}

This study is recommended to potential investors who are about to step into the financial markets to start chasing their dreams because it will assist them to be in a position to understand the nature of the paying companies and vice versa. This is because the study has explained very well determinants of dividends parallel with company policies and 
relationships to each factor mentioned. Understanding determinants will help investors to anticipate their future financial position from their company of choice for investment.

\section{Reference}

Adaoglu, C. (2000). Instability in the dividend policy of the Istanbul Stock Exchange (ISE) corporations: evidence from an emerging market. Emerging Markets Review, 1(3), 252-270. https://doi.org/10.1016/S1566-0141(00)00011-X

Adaoglu, C. (2008). Dividend policy of the ISE industrial corporations: The evidence revisited (1986-2007). Journal of BRSA Banking and Financial Markets, 2-2, 113-135.

Aivazian, V., Booth, L., \& Cleary, S. (2003). Dividend policy and the organization of capital markets. Journal of Multinational Financial Management, 13(2), 101-121.

https://doi.org/10.1016/S1042-444X(02)00038-5

Alli, K., Khan, A., ^ Ramirez, G. (1993), Determinants of dividend policy: a factorial analysis, Finance Rev, 28, 523-547. https://doi.org/10.1111/j.1540-6288.1993.tb01361.x

Altiok-Yilmaz, A., \& Akben, S. E. (2010). Information Content of Dividends: Evidence from Istanbul. International Business Research, 3(3), 126. https://doi.org/10.5539/ibr.v3n3p126

Amidu, M., \& Abor, J. (2006). Determinants of dividend payout ratios in Ghana. The Journal of Risk Finance, 7(2), 136-145. https://doi.org/10.1108/15265940610648580

Baker, H. K., \& Powell, G. E. (1999). How corporate managers view dividend policy? Quarterly Journal of Business and Economics, 38(2), 17-35.

Brealey, R. A., \& Myers, S. C. (2002). Financing and risk management. New York, NY: McGraw-Hill.

DeAngelo, H., DeAngelo, L., \& Skinner, D. J. (2004). Are dividends disappearing? Dividend concentration and the consolidation of earnings. Journal of Financial Economics, 72(3), 425-456. https://doi.org/10.1016/S0304-405X(03)00186-7

Lintner, J. (1956). Distribution of Incomes of Corporations among Dividends, in the European Union. Journal of Financial Economics, 89(2), 347-374.

Baker, H. K., \& Powell, G. E. (1999). How corporate managers view dividend policy? Quarterly Journal of Business and Economics, 38(2), 17-35.

Brealey, R. A., \& Myers, S. C. (2002). Financing and risk management. New York, NY: McGraw-Hill.

Lease, R. C. (2000). Dividend policy: Its impact on firm value. Boston, MA: Harvard Business School Press.

Lintner, J. (1956). Distribution of Incomes of Corporations among Dividends, Miller, M. H., \& Modigliani, F. (1961). Dividend policy, growth, and the valuation of shares. Foundations for Financial Management: a Book of Readings / Edited by James Van Horne. 


\section{Ml Macrothink}

Business and Economic Research ISSN 2162-4860 2017, Vol. 7, No. 2

Denis, D. J., \& Osobov, I. (2008). Why do Firms Pay Dividends? International Different Dividend Policies from U.S. Firms? The Journal of Financial Research, 41(6), 58-82

Denis, D. J., \& Osobov, I. (2008). Why do firms pay dividends? International evidence on the determinants of dividend policy. Journal of Financial Economics Amsterdam, 89(1), 62-82. https://doi.org/10.1016/j.jfineco.2007.06.006

Fama, E. F., \& Babiak, H. (1968). Dividend policy: An empirical analysis. Journal of the American Statistical Association, 63, 1132-1161.

https://doi.org/10.1080/01621459.1968.10480917

Fama, E. F., \& French, K. R. (2001). Disappearing dividends: Changing firm characteristics or lower propensity to pay? Journal of Financial Economics, 60, 3-43.

https://doi.org/10.1016/S0304-405X(01)00038-1

Ferris, S. P., Sen, N., \& Yui, H. P. (2006b). Are Fewer Firms Paying More Dividends? The International Evidence. Journal of Multinational Financial Management, 16(4), 333-362. https://doi.org/10.1016/j.mulfin.2005.08.002

Grullon, G., Michaely, R., \& Swaminathan, B. (2002). Are dividend changes a sign of firm maturity? Journal of Business, 75(3), 387-424. https://doi.org/10.1086/339889

Jensen, M. C., \& Meckling, W. H. (1976). Theory of the firm: Managerial behavior, agency costs, and ownership structure. Journal of Financial Economics, 3, 305-360.

https://doi.org/10.1016/0304-405X(76)90026-X

Kirkulak, B., \& Kurt, G. (March 01, 2010). Are dividends disappearing or shrinking? Evidence from the Istanbul stock exchange. Emerging Markets Finance and Trade, 46(2), 38-52. https://doi.org/10.2753/REE1540-496X460203

Kuzucu, N. (2015). A Survey of managerial perspective on corporate dividend policy: Evidence from Turkish listed firms. International Journal of Research in Business and Social Science, 4(2), 1-19. https://doi.org/10.20525/ijrbs.v4i2.22

Lease, R. C. (2000). Dividend policy: Its impact on firm value. Boston, MA: Harvard Business School Press.

Michel, A. (1979). Industry influence on dividend policy. Financial Management, 8(3), 22-26. https://doi.org/10.2307/3665034

Miller, M. H., \& Modigliani, F. (1961). Dividend policy, growth, and the valuation of shares. Foundations for Financial Management: a Book of Readings / Edited by James Van Horne.

Miller, M. H., \& Modigliani, F. (1961). Dividend policy, growth, and the valuation of shares. Journal of Business, 34. 411-433. https://doi.org/10.1086/294442

Naceur, S. B., Goaied M., \& Belanes, A. (2006). On the Determinants and Dynamics of Dividend Policy, International Review of Finance, 6(1-2), 1-23.

https://doi.org/10.1111/j.1468-2443.2007.00057.x 


\section{Al Macrothink}

Business and Economic Research

ISSN 2162-4860 2017, Vol. 7, No. 2

Pruitt, S. W., \& Gitman, L. J. (1991). The interactions between the investment, financing and dividend decisions of major US firms. Financial Review, 26(3), 409-430.

https://doi.org/10.1111/j.1540-6288.1991.tb00388.x

Reddy, Y. S., \& Rath, S. (2005). Disappearing Dividends in Emerging Markets? Retained Earnings and Taxes. American Economic Review, 46, 97-133.

Rozeff, M. S. (1982a). Growth, beta, and agency costs as determinants of dividend payout ratios. Journal of Financial Research, 5(3), 249-259.

https://doi.org/10.1111/j.1475-6803.1982.tb00299.x

Rozeff, M. S. (1982b). Industry influence on dividend policy in a firm-specific model. Working paper series, 82-21.

Skinner, D. J., \& Soltes, E. F. (2011). What do dividends tell us about earnings quality? Review of Accounting Studies, 16(1), 1-28. https://doi.org/10.1007/s11142-009-9113-8

Smith, C. W., \& Watts, R. L. (1992). The investment opportunity set and corporate financing, dividend, and compensation policies. Journal of Financial Economics, 32(3), 263-292.

https://doi.org/10.1016/0304-405X(92)90029-W

Yilmaz, M. K. (2003). An analysis on the dividend policy of the Istanbul Stock Exchange (ISE) corporations: Cash dividend - industry behavior relation. The Istanbul Stock Exchange (ISE) Review, 7(25\&26), 17-39.

\section{Copyright Disclaimer}

Copyright for this article is retained by the author(s), with first publication rights granted to the journal.

This is an open-access article distributed under the terms and conditions of the Creative Commons Attribution license (http://creativecommons.org/licenses/by/3.0/). 